www.jmscr.igmpublication.org

Index Copernicus Value: 79.54

ISSN (e)-2347-176x ISSN (p) 2455-0450

crossref DOI: https://dx.doi.org/10.18535/jmscr/v7i4.76

Journal Of Medical Science And Clinical Research

IGM Publication

An Official Publication of IGM Publication

\title{
A study to compare the antiemetic efficacy of ondansetron and dexamethasone with the combination of ramosetron and dexamethasone in middle ear surgery
}

\author{
Authors \\ Dr Shivakumar KP' ${ }^{1}$, Dr Nishant Agrawal ${ }^{2}$, Dr Arun Kumar Ajjappa ${ }^{3}$ \\ ${ }^{1}$ Professor, Dept. of Anaesthesia, S S Institute of Medical Science and Research Centre, Davangere, \\ Karnataka \\ ${ }^{2}$ Postgraduate, Dept. of Anaesthesia, S S Institute of Medical Science and Research Centre, Davangere, \\ Karnataka \\ ${ }^{3}$ Professor and Head, Dept. of Anaesthesia, S S Institute of Medical Science and Research Centre, \\ Davangere, Karnataka
}

\begin{abstract}
Introduction: Postoperative nausea and vomiting is one of the most important complications after anesthesia and surgery, with a relatively high incidence after middle ear surgery. Selective 5-HT3 antagonists are considered first line for prophylaxis, ondansetron being most commonly used agent and ramosetron being more potent and long acting.

Methods: 74 patients admitted to SSIMS\&RC for middle ear surgeries, were divided into group RD and group OD. Group RD received ramosetron $0.3 \mathrm{mg}$ and dexamethasone $8 \mathrm{mg}$ whereas group OD received ondansetron $4 \mathrm{mg}$ and dexamethasone $8 \mathrm{mg} 30$ minutes before the end of surgery.

The incidence of postoperative nausea, retching, vomiting and the requirement of rescue antiemetic was recorded over 0-6hrs and 6-24 hrs.

Results: The incidence of vomiting (p-0.027) and the requirement of rescue antiemetic(p-0.003) was significantly less in group which received the combination of ramosetron and dexamethasone when compared to the group which received ondansetron and dexamethasone. There was no statistical difference with regard to the incidence of nausea $(p-0.183)$ and retching $(p-0.286)$ between both the groups during 0 6hrs postoperatively. During 6-24hrs postoperatively, there was no statistical difference between both the groups in terms of nausea ( $p-0.50)$, retching ( $p-0.50)$, vomiting $(p-0.50)$ and requirement of rescue antiemetic.

Conclusion: We conclude by our study that the combination of ramosetron and dexamethasone is superior to ondansetron and dexamethasone for the prophylaxis of PONV in middle ear surgeries.
\end{abstract}

\section{Introduction}

Postoperative nausea and vomiting is one of the most important complications after anesthesia and surgery, with a relatively high incidence after middle ear surgery as the middle ear surgery involves the stimulation of labyrinth. ${ }^{1}$ Ramosetron is a newer $5-\mathrm{HT}_{3}$ receptor antagonist which is more potent and has a longer duration of antiemetic action because of its higher binding affinity, slower rate of dissociation from the target 
receptor and longer elimination half-life. ${ }^{1-4}$ Studies have shown that ramosetron is more effective than ondansetron in preventing postoperative nausea and vomiting among the patients undergoing various surgeries. ${ }^{1,5}$ Dexamethasone has been successfully used as an adjunct to $5 \mathrm{HT}_{3}$ antagonist resulting in enhanced antiemetic efficacy with minimal side effects and has prolonged duration of action. ${ }^{1,6,7}$

Therefore, we aimed to compare the antiemetic efficacy of Ondansetron and Dexamethasone with Ramosetron and Dexamethasone for the prophylaxis of post-operative nausea and vomiting upto 24 hours after the middle ear surgery.

\section{Materials and Methods \\ Source of Data}

The data for the study was collected from the patients admitted to S.S. Institute Of Medical Sciences \& Research Centre, for middle ear surgeries over a period of 3 months.

\section{Sample Size}

In a preliminary study on subjects who were administered ondansetron with dexamethasone and ramosetron with dexamethasone intravenously, 30 minutes before the end of surgery, the post-operative nausea and vomiting incidence at $0-24 \mathrm{~h}$ was found to be $40 \%{ }^{2}$ The sample size was calculated using previous study and power of $80 \%$, showed that 33 patients per group will be sufficient to detect the antiemetic effect of ramosetron and dexamethasone as compared to ondansetron and dexamethasone. Assuming a $10 \%$ dropout rate, the final sample size is set at 37 patients per group (total 74 patients)

\section{Inclusion Criteria}

- ASA grade I \& II patients.

- Patients in the age group of 18 to 65 years of age.

\section{Exclusion Criteria}

- ASA grade III and grade IV patients.

- Patients of age less than 18 and more than 65 years.
- Patients with gastrointestinal diseases, renal dysfunction and diabetes mellitus.

- Pregnant and menstruating women.

- Patients who had received any anti emetic medication within 24 hours before surgery.

- Patients who had received steroids within 24 hours before surgery.

- Patients who don't give valid consent.

\section{Method of Collection of Data}

Anon-randomized study was conducted at S.S. institute of medical sciences \& research centre, Davangere.

Patients for middle ear surgery under general anaesthesia were taken for the study. After obtaining a written informed consent and institutional ethical committee approval, every patient underwent general physical examination. The patients were instructed to avoid solid food for 6 hours before surgery. After arriving in the operating room an IV line was secured with an 20G cannula. A 3 lead ECG monitor, pulse oximeter and an automated non-invasive arterial blood pressure monitor was connected. The patients were induced with thiopentone $(5 \mathrm{mg} / \mathrm{kg})$ intravenously. Vecuronium $(0.1 \mathrm{mg} / \mathrm{kg})$ intravenous was used to facilitate tracheal intubation. Anaesthesia was maintained with 0.5 $2 \%$ isoflurane, $33 \%$ oxygen in nitrous oxide. Intraoperative analgesia was provided with IV fentanyl (2-3mcg/kg) and diclofenac $(2 \mathrm{mg} / \mathrm{kg}) \mathrm{IV}$. At the end of surgery, residual neuromuscular block was reversed with neostigmine $(0.05 \mathrm{mg} / \mathrm{kg})$ and glycopyrrolate $(0.01 \mathrm{mg} / \mathrm{kg}) \mathrm{IV}^{2}$ The subjects were divided into two groups. One group received ondansetron $4 \mathrm{mg}+$ dexamethasone $8 \mathrm{mg}$ and the other group will receive ramosetron $0.3 \mathrm{mg}+$ dexamethasone $8 \mathrm{mg}$ IV $30 \mathrm{~min}$ before the end of surgery. Post-op analgesia was provided with paracetamol or diclofenac. ${ }^{2}$

The incidence of post-op nausea and vomiting and the need for rescue antiemetic was recorded over the next 24 hours, which was divided into 2 intervals (early and late) : 0-6 hours and 6-24 hours respectively. ${ }^{2}$ 


\section{Results}

Table 1 Characteristics of Age Distribution

\begin{tabular}{|c|c|c|c|c|}
\hline \multirow[b]{2}{*}{ Age (in years) } & \multicolumn{2}{|c|}{ GROUP } & \multirow[b]{2}{*}{ Total } & \multirow[b]{2}{*}{$\mathrm{p}$ value } \\
\hline & Group RD & Group OD & & \\
\hline \multirow{2}{*}{$\leq 20$} & 1 & 3 & 4 & \multirow{12}{*}{0.045} \\
\hline & $2.7 \%$ & $8.1 \%$ & $5.4 \%$ & \\
\hline \multirow[t]{2}{*}{$21-30$} & 12 & 10 & 22 & \\
\hline & $32.4 \%$ & $27.0 \%$ & $29.7 \%$ & \\
\hline \multirow[t]{2}{*}{$31-40$} & 19 & 9 & 28 & \\
\hline & $51.4 \%$ & $24.3 \%$ & $37.8 \%$ & \\
\hline \multirow[t]{2}{*}{$41-50$} & 3 & 9 & 12 & \\
\hline & $8.1 \%$ & $24.3 \%$ & $16.2 \%$ & \\
\hline \multirow[t]{2}{*}{$>50$} & 2 & 6 & 8 & \\
\hline & $5.4 \%$ & $16.2 \%$ & $10.8 \%$ & \\
\hline \multirow[t]{2}{*}{ Total } & 37 & 37 & 74 & \\
\hline & $100.0 \%$ & $100.0 \%$ & $100.0 \%$ & \\
\hline
\end{tabular}

Graph 1: Characteristics of Age Distribution

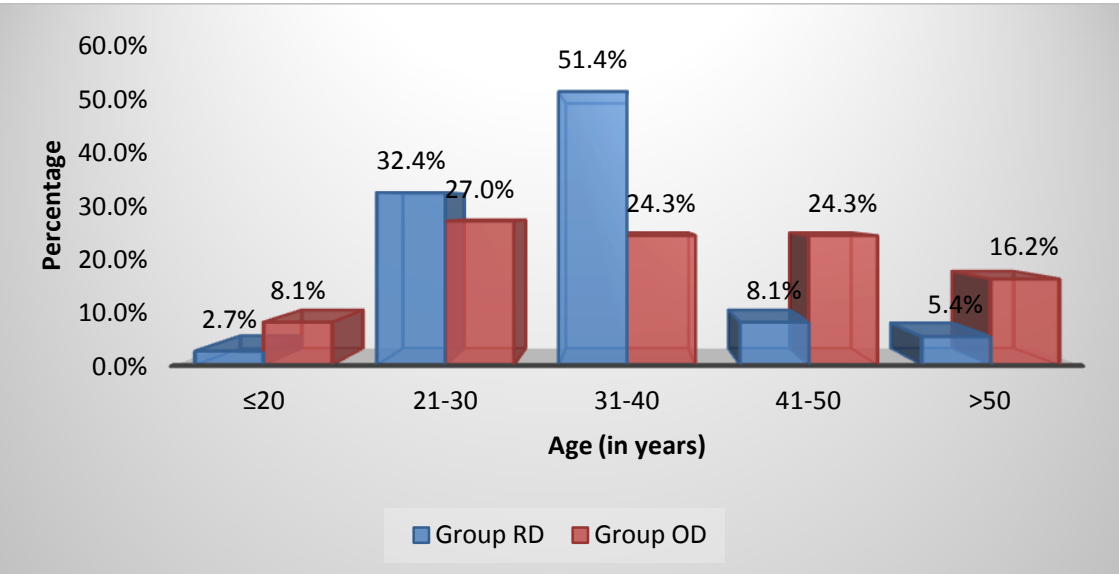

Both the groups are comparable with respect to age.

Table 2: Characteristics of Gender Distribution

\begin{tabular}{|l|c|c|c|c|}
\hline \multirow{2}{*}{ Sex } & \multicolumn{2}{|c|}{ GROUP } & \multirow{2}{*}{ Total } & \multirow{2}{*}{ p value } \\
\cline { 2 - 3 } & Group RD & Group OD & \\
\cline { 2 - 3 } Male & 16 & 17 & 33 & \\
\cline { 2 - 4 } & $43.2 \%$ & $45.9 \%$ & $44.6 \%$ & \\
\hline \multirow{3}{*}{ Female } & 21 & 20 & 41 & \multirow{3}{*}{0.815} \\
\cline { 2 - 4 } & $56.8 \%$ & $54.1 \%$ & $55.4 \%$ & \\
\hline \multirow{2}{*}{ Total } & 37 & 37 & 74 & \\
\cline { 2 - 4 } & $100.0 \%$ & $100.0 \%$ & $100.0 \%$ & \\
\hline
\end{tabular}

Graph 2: Characteristics of Gender Distribution

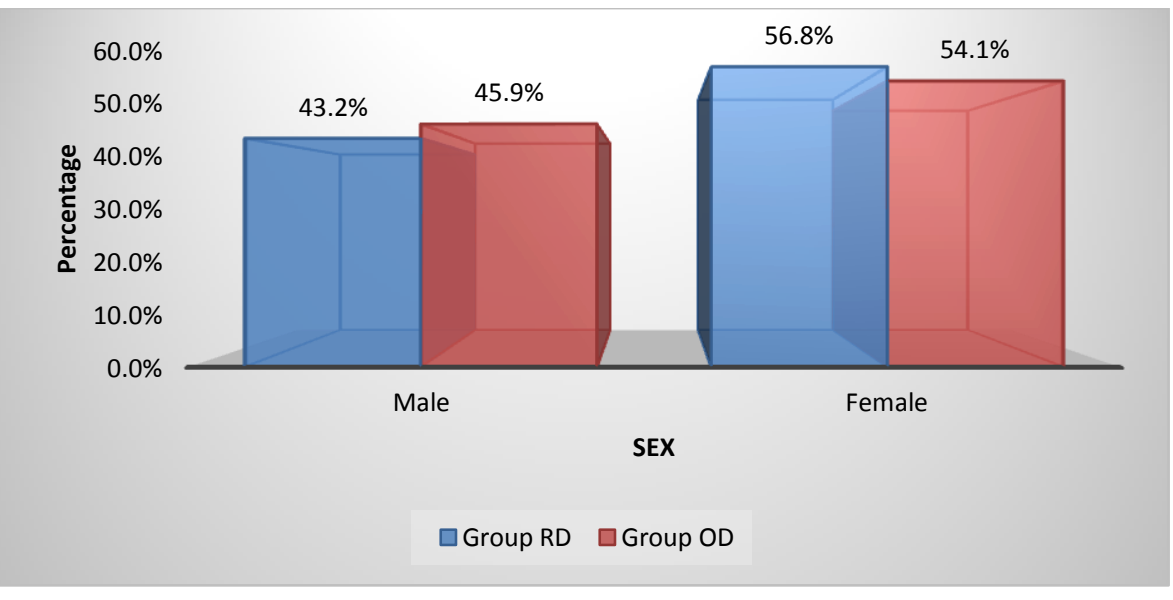




\section{JMSCR Vol||07||Issue||04||Page 444-450||April}

In our study, out of 74 patients, 16 patients (43.2\%) were males and 21 patients $(56.8 \%)$ were females in Group RD whereas there were 17 male patients (45.9\%) and 20 female patients $(54.1 \%)$ in Group OD.

Table 3: Characteristics of ASA Distribution

\begin{tabular}{|l|c|c|c|c|}
\hline \multirow{2}{*}{ ASA Grade } & \multicolumn{2}{|c|}{ GROUP } & \multirow{2}{*}{ T value } \\
\cline { 2 - 3 } \cline { 2 - 3 } & Group RD & Group OD & & \\
\hline \multirow{2}{*}{1} & 37 & 33 & 70 & \\
\cline { 2 - 3 } & $100.0 \%$ & $89.2 \%$ & $94.6 \%$ & \\
\cline { 2 - 3 } & 0 & 4 & 4 & \multirow{3}{*}{$0.057 *$} \\
\hline \multirow{2}{*}{ Total } & $0.0 \%$ & $10.8 \%$ & $5.4 \%$ & \\
\cline { 2 - 3 } & 37 & 37 & 74 & \\
\cline { 2 - 3 } & $100.0 \%$ & $100.0 \%$ & $100.0 \%$ & \\
\hline
\end{tabular}

*-Fisher Exact Test

Graph 3: Characteristics of ASA Distribution

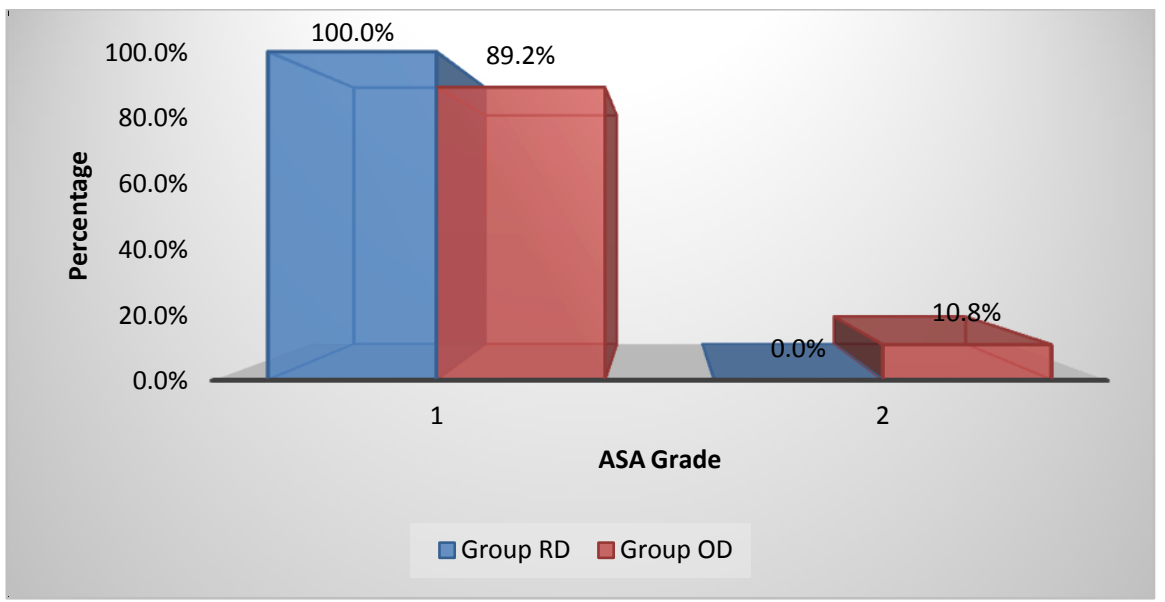

All 37 patients (100.0\%) in Group RD belonged to ASA 1 whereas 33 patients $(89.2 \%)$ belonged to

Table 4 Incidence of Nausea, Retching, Vomiting and Rescue anti emetic in 0-6 hrs interval.

\begin{tabular}{|c|c|c|c|c|c|}
\hline \multirow[b]{2}{*}{ AT 0-6 Hrs } & \multicolumn{2}{|c|}{ Group RD } & \multicolumn{2}{|c|}{ Group OD } & \multirow[b]{2}{*}{$\mathrm{p}$ value } \\
\hline & $\mathrm{N}$ & $\%$ & $\mathrm{~N}$ & $\%$ & \\
\hline Nausea & 7 & 18.92 & 12 & 32.43 & 0.183 \\
\hline Retching & 3 & 8.11 & 6 & 16.22 & 0.286 \\
\hline Vomiting & 0 & 0.00 & 5 & 13.51 & $0.027 *$ \\
\hline Rescue antiemetic & 0 & 0.00 & 8 & 21.62 & $0.003^{*}$ \\
\hline
\end{tabular}

*-Fisher Exact Test

Graph 4: Incidence of Nausea, Retching, Vomiting and Rescue anti emetic in 0-6 hrs interval.

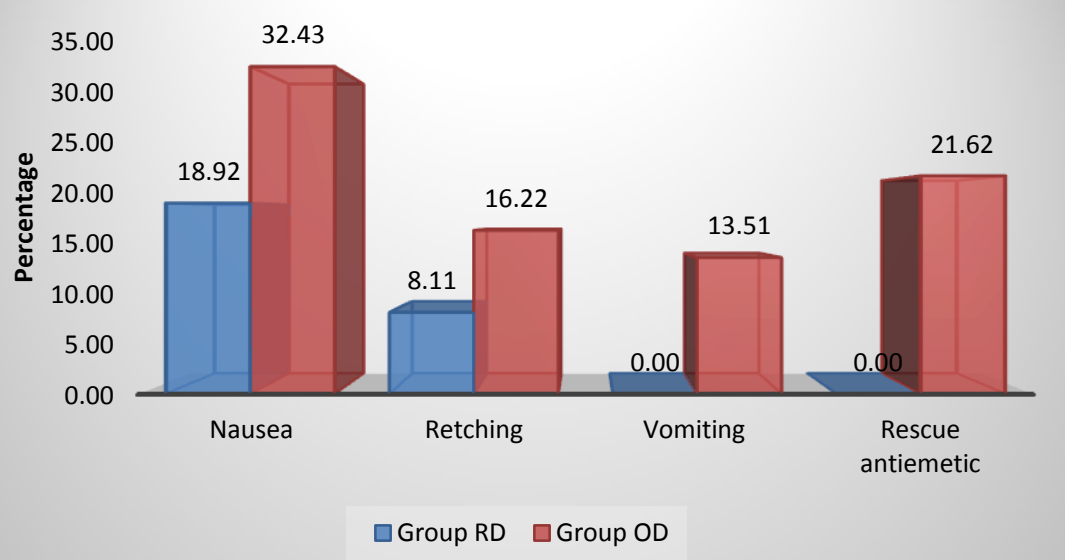


In our study, 7 patients( $18.92 \%)$ had nausea and 3 patients $(8.11 \%)$ had retching in Group RD whereas 12 patients $(32.43 \%)$ had nausea, 6 patients $(16.22 \%)$ had retching, 5 patients (13.51\%) had vomiting and 8 patients $(21.62 \%)$ required rescue anti-emetic in Group OD. p-value were statistically insignificant for nausea and retching, but were significant for vomiting $(\mathrm{p}=0.027)$ and the use of rescue anti-emetic $(\mathrm{p}=0.003)$ at $0-6 \mathrm{hrs}$ interval.

Table 5: Incidence of Nausea, Retching, Vomiting and Rescue anti emetic in 6-24 hrs interval.

\begin{tabular}{|l|c|c|c|c|c|}
\hline \multirow{2}{*}{ AT 6-24 Hrs } & \multicolumn{2}{|c|}{ Group RD } & \multicolumn{2}{|c|}{ Group OD } & \multirow{2}{*}{ p value } \\
\cline { 2 - 5 } & $\mathrm{N}$ & $\%$ & $\mathrm{~N}$ & $\%$ & $0.500^{*}$ \\
\hline Nausea & 0 & 0.00 & 1 & 2.70 & $0.500^{*}$ \\
\hline Retching & 0 & 0.00 & 1 & 2.70 & $0.500^{*}$ \\
\hline Vomiting & 0 & 0.00 & 1 & 2.70 & \\
\hline Rescue antiemetic & 0 & 0.00 & 0 & 0.00 & \\
\hline
\end{tabular}

*-Fisher Exact Test

Graph 5: Incidence of Nausea, Retching, Vomiting and Rescue anti emetic in 6-24 hrs interval.

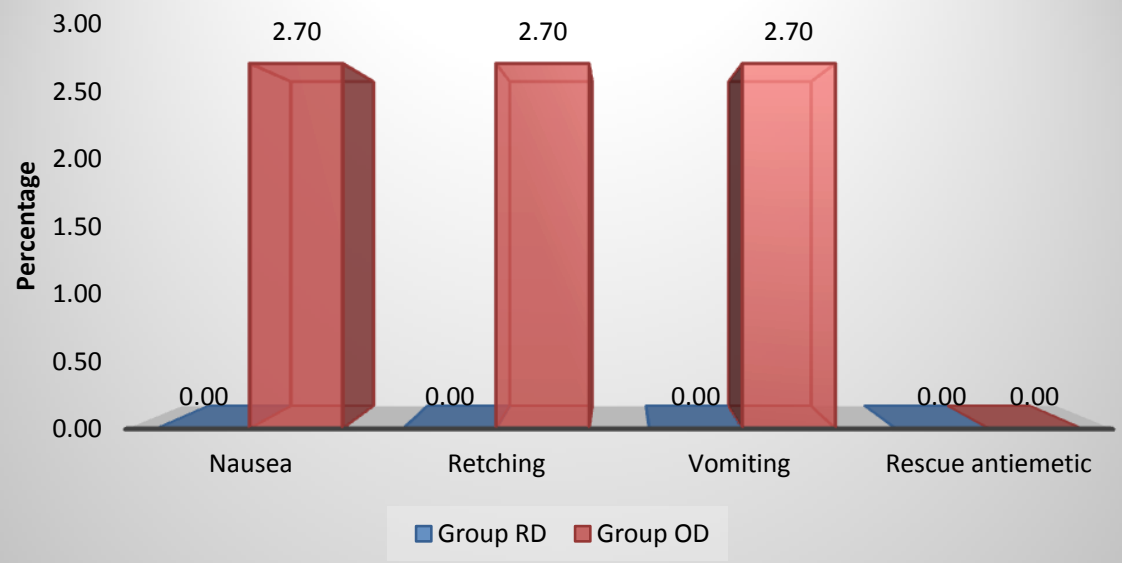

In our study, none of the patients had nausea, retching, vomiting or required rescue anti emetic in Group RD whereas 1 patient $(2.70 \%)$ had nausea, $1(2.70 \%)$ had retching and $1(2.70 \%)$ had vomiting and none required rescue anti emetic in Group OD and the results were statistically insignificant.

\section{Discussion}

One of the most important complications of middle ear surgery is post-operative nausea and vomiting (PONV) due to the stimulation of labyrinth, with an incidence upto $80 \%$ when no anti-emetics are used. ${ }^{8}$

Studies have shown that ondansetron is more effective in preventing early but not late PONV, whereas dexamethasone was found to have more pronounced action in the late post-operative period, due to the shorter duration of action of ondansetron (4 hours) in contrast to prolonged duration of action of dexamethasone and thus, combination of ondansetron and dexamethasonecan decrease the incidence of both early and late nausea and vomiting., 9

Ramosetron is a newer 5-HT3 receptor antagonist which has longer duration of anti-emetic action and is more potent when compared to the older drugs. This is due to the higher binding capacity and slower rate of dissociation of Ramosetron from its target receptor when compared to ondansetron, and also, the elimination half-life of Ramosetron is longer (9 hours) when compared to Ondansetron (4hours). ${ }^{11}$ Many of the recent studies have shown that Ramosetron is more effective than Ondansetron in preventing PONV for patients undergoing various surgeries. ${ }^{12}$

The glucocorticoid, dexamethasone also produces anti-emetic effect due to the release of endorphins 
and inhibits prostaglandin and serotonin production. $^{13}$

Combination of two anti-emetics, ondansetron and dexamethasone had better efficacy than single drug when being used as a prophylaxis for PONV. This is similar to the conclusion of other metanalysis, according to which combination of antiemetics is superior to individual drug when used for the prophylaxis of PONV. ${ }^{14}$

Since the etiology of PONV following middle ear surgeries is multi-factorial, it is recommended that drugs with different mechanisms of action should be used in combination to optimize the efficacy. ${ }^{15}$ As there are abundant 5-HT3 receptors present in the vicinity of trigeminal nerve and vestibular labyrinth, 5-HT3 receptor antagonists are efficacious in middle ear surgeries.

Dexamethasone can significantly reduce the tissue inflammation and thereby reduces the ascending impulse to the vomiting centre in the brain and also improves the action of other anti-emetics by sensitizing the pharmacologic receptors to the other anti-emetic drugs. ${ }^{15}$

Therefore, the combination of 5-HT3 receptor antagonists and dexamethasone have an additive effect in reducing PONV and hence this study was carried out to compare the anti-emetic efficacy of ramosetron and dexamethasone with ondansetron and dexamethasone for prophylaxis of PONV in patients undergoing middle ear surgery.

\section{Limitations of the Study}

1) We observed patients for only 24 hours postoperatively and hence long term complications of glucocorticoids such as impaired wound healing, wound infection are not known.

2) Also, patients with diabetes mellitus were excluded from the study, as studies have reported that administration of glucocorticoids like dexamethasone in the intra-operative period, resulted in increased post-operative blood glucose concentrations.

\section{Conclusion}

In conclusion, combined $0.3 \mathrm{mg}$ Ramosetron and $8 \mathrm{mg}$ of Dexamethasone intravenous is more effective than $4 \mathrm{mg}$ Ondansetron and $8 \mathrm{mg}$ of Dexamethasone intravenous for the prophylaxis of post-operative nausea and vomiting during the first 24 hours in patients undergoing middle ear surgeries.

\section{References}

1. Desai S, Santosh MCB, Annigeri R, Santoshi VB, Rao R. Comparison of the antiemetic effect of ramosetron with combination of dexamethasone and ondensetron in middle ear surgery: A double-blind, randomized clinical study. Saudi J Anaesth 2013;7(3):254-8.

2. Agarkar S, Chatterjee AS. Comparison of ramosetron with ondansetron for the prevention of post operative nausea and vomiting in high risk patients. Indian $\mathbf{J}$ Anaesth 2015;59:222-7.

3. Yang SY et al. Efficacy of dexamethasone added to ramosetron for preventing post operative nausea and vomiting in highly susceptible patients following spine surgery. Korean J Anesthesiol 2012;62(3):260-5.

4. Lee MJ et al. Comparison of ramosetron plus dexamethasone with ramosetron alone on post operative nausea, vomiting, shivering and pain after thyroid surgery. Korean J Pain 2015;28:39-44.

5. Hahm TS, Ko JS, Choi SJ and Gwak MS. Comparison of prophylactic antiemetic efficacy of ramosetron and ondansetron in patients at high-risk for post operative nausea and vomiting after total knee replacement. Anesthesia 2010;65:500-4.

6. Ryu JH et al. Ramosetron vsramosetron plus dexamethasone for the prevention of post operative nausea and vomiting after laparoscopic cholecystectomy: Prospective, randomized and double-blind study. Int. J S 2013;11:183-7. 
7. Choi YS, Shim JK, Ahn SH and Kwak YL. Efficacy comparison of ramosetron with ondansetron on preventing nausea and vomiting in high-risk patients following spine surgery with a single bolus of dexamethasone as an adjunct. Korean J Anesthesiol 2012;62:543-7.

8. Honkavaara P, Saarinvaara L, Klemola UK. Prevention of nausea and vomiting with transdermal hyocine in adults after middle ear surgery during general anaesthesia.Br J Anaesth. 1994;73:763-6.

9. Olaondo LL et al. Combination of ondansetron and dexamethasone in the prophylaxis of postoperative nausea and vomiting.Br J Anaesth. 1996;76:835-40.

10. Rajeeva V, Bharadwaj N, Batra YK, Dhaliwal LK. Comparison of ondansetron with ondansetron and dexamethasone in preventing PONV in diagnostic laparoscopy. Can J Anaesth. 1999;46:40-4.

11. Gan TJ. Selective serotonin 5-HT3 receptor antagonists for postoperative nausea and vomiting. Are they all the same? CNS Drugs. 2005;19:225-38.

12. Lee JW et al. Comparison of ramosetron's and ondansetron's preventive anti-emetic effects in highly susceptible patients undergoing abdominal hysterectomy Korean J Anaesthesiol. 2011;61:488-92.

13. Holte K, Kehlet H. Peri-operative single dose glucocorticoid administration: pathophysiologic effects and clinical implications. Journal of the American college of Surgeons 2002;195(5):694-712.

14. Gan $T$ et al. Society for ambulatory anaesthesia guidelines for the management of postoperative nausea and vomiting Anaesth Analg. 2007;105:1615-28.

15. Sagar S. The current role of anti-emetic drugs in oncology: A recent revolution in patient symptom control. Cancer Treat Rev.1991;18:95-135. 